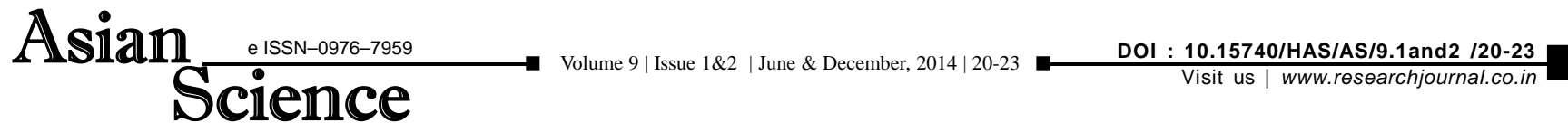

RESEARCH PAPER

\section{A study on awareness of HIV/AIDS among students in Annamalai University}

\author{
J. VIJAYALAKSHMI*AND MUVANDIMWE EMMANUEL \\ Department of Population Studies, Annamalai University, Annamalai Nagar, CHIDAMBARAM (T.N.) INDIA \\ (Email: muva2013@gmail.com)
}

\begin{abstract}
HIV is a virus that causes AIDS. It enters the body and infects immune system cells in the body, causing more copies of the virus to be produced. AIDS stands for Acquired Immune Deficiency Syndrome. HIV/AIDS is becoming an important problem in India and south Asia. Young and reproductive age groups of the population are at the centre of the HIV epidemic in India. Since 1997, the disease has been spreading rapidly among intravenous drug users and commercial sex workers (Shankar et al., 2009). In this study a sample of 100 respondents was randomly selected from the students of engineering faculty in Annamalai University. Personal interview method was adopted for data collection and analysis was done through frequency and percentage. The result revealed that all respondents (100\%) had heard about HIV/AIDS. It has been observed that majority of respondents (95\%) had agreed that sex with multiple partner was a source of HIV infection to people. In this paper an attempt has been made to assess the knowledge about health problems of HIV/AIDS and preventive methods among students.
\end{abstract}

Key Words : Awareness, HIV/AIDS, Among students

View point paper : Vijayalakshmi, J. and Emmanuel, Muvandimwe (2014). A study on awareness of HIV/AIDS among students in Annamalai University. Asian Sci., 9 (1\&2): 20-23. 